\title{
The Forest Energy Chain in Tuscany: Economic Feasibility and Environmental Effects of Two Types of Biomass District Heating Plant
}

\author{
Claudio Fagarazzi ${ }^{1, *}$, Alessandro Tirinnanzi ${ }^{1}$, Mario Cozzi ${ }^{2}$, Francesco Di Napoli ${ }^{2}$ \\ and Severino Romano ${ }^{2}$
}

1 Department of Agricultural, Food and Forest Systems Management - GESAAF, University of Florence, Firenze 50144, Italy; E-Mail: alessandro.tirinnanzi@unifi.it

2 School of Agricultural Sciences, Forestry, Food and Environment-SAFE, University of Basilicata, Potenza 85100, Italy; E-Mails: mario.cozzi@unibas.it (M.C.); francesco.dinapoli@unibas.it (F.D.N.); severino.romano@unibas.it (S.R.)

* Author to whom correspondence should be addressed; E-Mail: claudio.fagarazzi@unifi.it; Tel.: +39-55-275-5793; Fax: +39-55-361-771.

Received: 26 January 2014; in revised form: 19 August 2014 / Accepted: 27 August 2014 / Published: 10 September 2014

\begin{abstract}
The purpose of this study was to examine two biomass district heating plants operating in Tuscany, with a specific focus on the ex-post evaluation of their economic and financial feasibility and of their environmental benefits. The former biomass district heating plant supplies only public users (Comunità Montana della Lunigiana, CML: administrative body that coordinates the municipalities located in mountain areas), the latter supplies both public and private users (Municipality of San Romano in Garfagnana). Ex-post investment analysis was performed to check both the consistency of results with the forecasts made in the stage of the project design and on the factors, which may have reduced or jeopardized the estimated economic performance of the investment (ex-ante assessment). The results of the study point out appreciable results only in the case of biomass district heating plants involving private users and fuelled by biomasses sourced from third parties. In this case, the factors that most influence ex-post results include the conditions of the woody biomass local market (market prices), the policies of energy selling prices to private users and the temporal dynamics of private users' connection. To ensure the consistency of ex-post economic outcome with the expected results it is thus important to: (i) have good knowledge of the woody local market; (ii) define energy selling prices that should be cheap for private users but consistent with energy production costs and (iii) constrain private
\end{abstract}


users beforehand to prevent errors in the plant design and in the preliminary estimate of return on investment. Moreover, the results obtained during the monitoring activities could help in providing information on the effectiveness of the supporting measures adopted and also to orient future choices of policy makers and particularly designers, to identify the most efficient configuration of district heating organization for improving energy and environmental performances of communities, and to develop a chain model for the optimization of energy use in the municipality.

Keywords: renewable energy; biomass woodchips; economic feasibility; economic evaluation; forest energy chain; district heating; environmental effects

\section{Introduction}

In Tuscany, funding programs designed to favor the development of agro-forestry biomass-based energy chains have been implemented since 2006.

This has made it possible to build over 100 thermal and cogeneration plants having a power ranging from 200 thermal $\mathrm{KW}$ to 5.6 thermo-electric MW, with economic and environmental benefits to the forestry and the manufacturing sectors linked with the production of renewable technologies.

This evolutionary trend, partly favored by the European policies in support of renewable energies (under Directives 2009/28/EC [1], 2004/8/EC [2], 2001/77/EC [3], etc.), has never been followed by the monitoring of the economic and environmental effects caused by those investments. No assessments are available at the chain level or on the regional scale. Testing was related only to the construction and operation of plants.

Assessments are instead decisive to test the effectiveness of the supporting measures taken, with a view to orienting future choices and identifying the most promising strategies for improving energy and environmental performances of communities [4].

The study, resulting from a three-year monitoring activity on some biomass district heating plants, is designed to check these effects on some local chains, while supplying methodological proposals to assess the economic feasibility of the investment and determine energy production costs.

In this regard, many authors have developed economic analyses on biomass district heating plants sometimes with controversial results [5-7]. Despite the high number of studies, no analysis was conducted on a major and influential factor for chain development, namely the possibility of having significant differences between ex-ante economic feasibility analysis and ex-post investment results. In practice, in the design stage (ex-ante) there could be information gaps which may have reduced or jeopardized the economic performance (ex-post). The factors that mostly influence this process include the conditions of the woody biomass local market (biomass prices); the policies of energy selling prices and the temporal dynamics of private users' connection.

Poor knowledge of the wood local market, ignorance of the correct procedures of acquisition of users, and wrong policies in setting energy selling prices may lead to errors in the sizing of the district heating plant and in the estimate of the return on investment. 
Based on the above, the study makes this comparison, by examining very closely two biomass district heating plants operating in Tuscany, with a specific focus on the ex-post analysis of their economic and financial feasibility as well as their environmental benefits. More specifically, it considers the district heating plant of the Comunità Montana della Lunigiana, which supplies only public users, and the district heating plant of Municipality of San Romano in Garfagnana, which supplies both public and private users. In the latter case, besides assessing the ex-post economic feasibility of the investment, the study has developed a sensitivity analysis of the investment with respect to two variables: the wood chip price and the selling energy price applied to private users.

This has allowed for the economic feasibility of the investment to also be evaluated for different market scenarios from the one under analysis, for example in areas with different biomass market prices or a diversified price of competitive fuels.

Moreover, the study proposes an operational accounting approach for the definition of the unit production costs of the thermal energy produced in mixed (public-private) plants, in particular in the plants that have two heat production lines, respectively: one for heating public utilities, and the other for heating private users (dwellings, businesses, etc.). The proposed approach is the full-costing method [8-12] to allocate indirect costs between public and private users. In the case of mixed (public-private) plants, this evaluation actually enables testing the compatibility between the production cost of the energy for private users and the related selling price.

The results obtained have confirmed large economic feasibility margins of biomass district heating plants designed for public facilities. In this case, the indicators of the investment feasibility are always extremely positive and in agreement with those defined in the stage of design. In the case of district heating plants designed for public facilities and for private users, results are always positive, but not actually as performing as in the previous case. In this configuration, the investment efficiency largely depends on the energy selling price for users, the purchase price of wood chips and private users' timing of connection.

\section{The Case-Study: Forest Chain of Comunità Montana della Lunigiana and Forest Chain of San Romano in Garfagnana}

In Tuscany, there are several configurations of the forest energy chain, based on district heating technologies with high efficiency boilers. These chains are based on the recovery of forest residue biomasses, their subsequent conversion in wood chips and their use in district heating plants. There are multiple configurations of district heating plants: small size plants with private users and private operators; small and large size plants with public users and private operators; large size plants owned by the State, with a private operator and public and private users; large size plants owned by the State, with a public operator and public and private users; and finally, large size plants owned by the State and with public operators exclusively for public users.

We refer to two district heating plants, which differ both in the forest energy chain and in the technical plant configuration. The two chains examined in this paper, Comunità Montana della Lunigiana (CML) and Municipality of San Romano in Garfagnana, are located in central Italy, in a mountainous area of the Tuscan Apennines (Figure 1). 
Figure 1. The forest energy chain examined (on the right), and a zoom on the district heating plants operating in Tuscany (red dots). For more information [13].

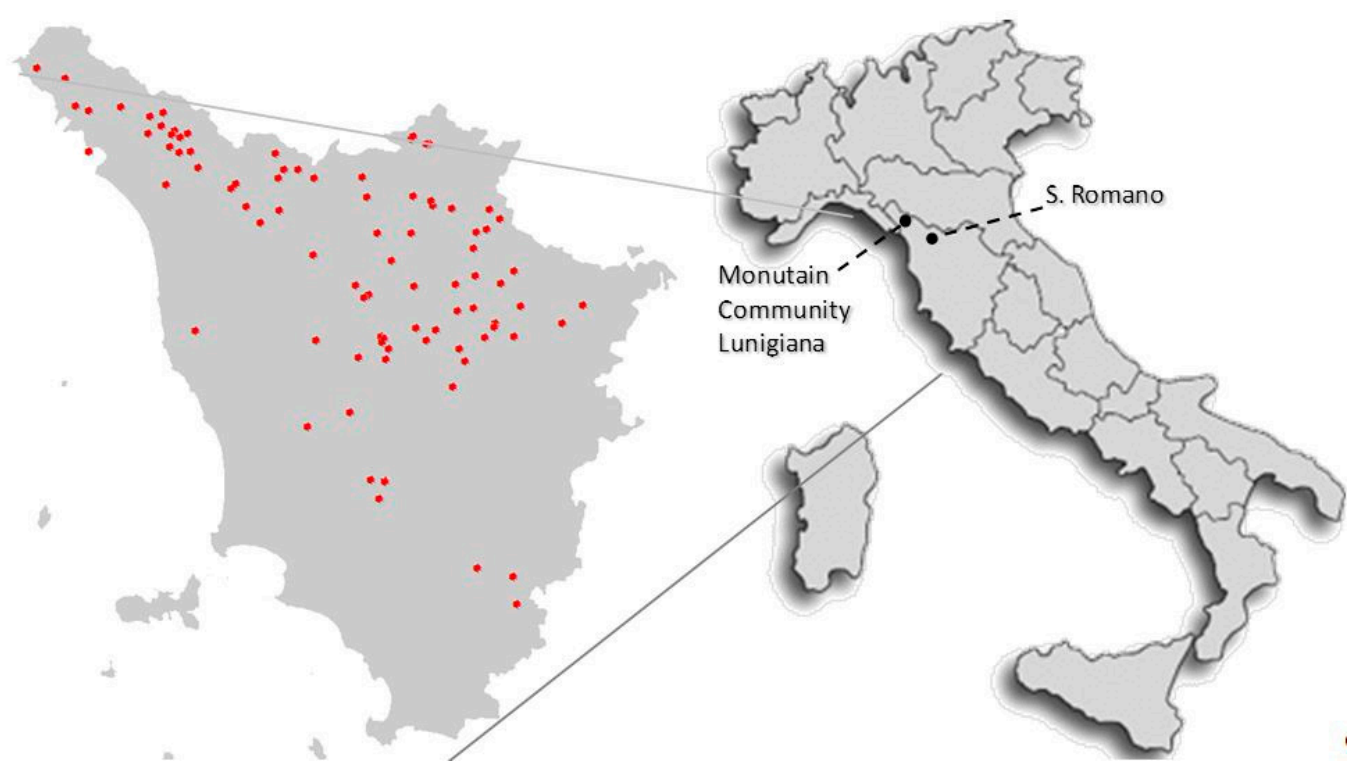

The aim of the study was to compare ex-post and ex-ante economic feasibility and identify the reason for the possible gap. The second step was to find the strengths and weaknesses of organizational options and suggest adjustments based on observations for improving energy efficiency and socio-economic performance [14].

The forest chain of CML is based on the production of wood chips sourced from the State forests. The district heating plant is managed by CML and provides the service to three public utilities (Figure 2).

Figure 2. Forest chain of Comunità Montana della Lunigiana.

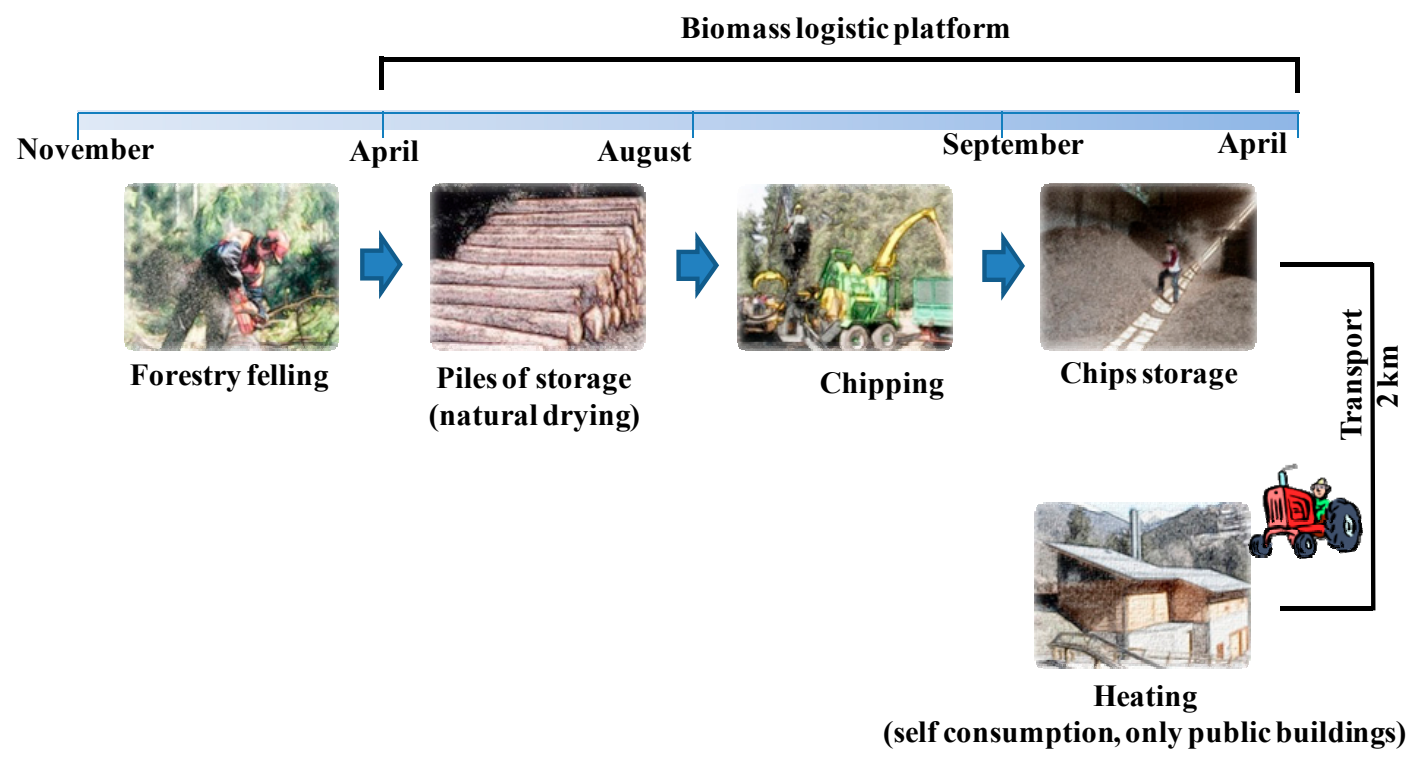

In the forest chain of Municipality of San Romano Garfagnana wood chips are sourced from local forestry companies and local sawmill and supplied to a district heating system for public facilities and private citizens (Figure 3). 
Figure 3. Forest chain of San Romano in Garfagnana.

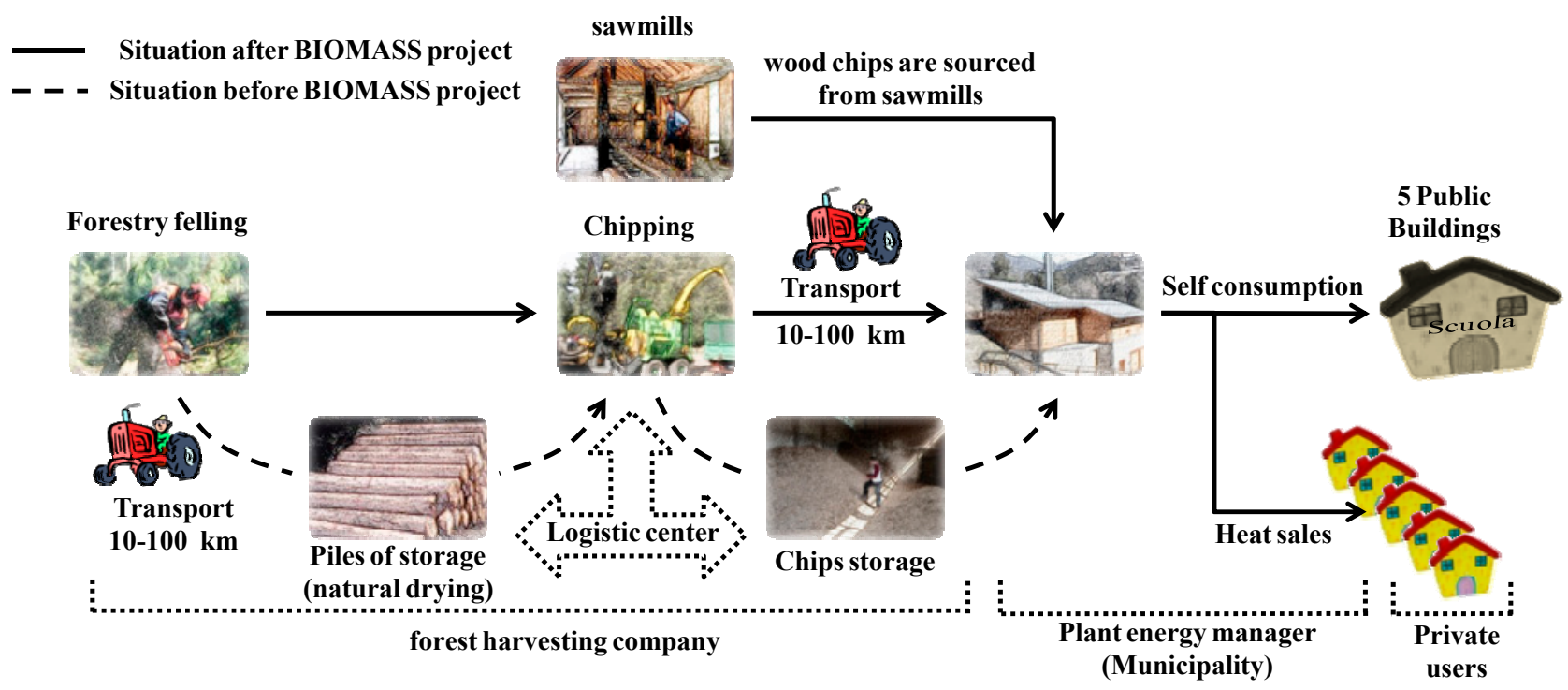

The first chain uses wood chips, resulting from environmental improvement activities, such as thinning and pruning, in forests located at distances from 5 to $50 \mathrm{~km}$ from the district heating plant. The logs are piled up within a logistic platform [15,16] located $2 \mathrm{~km}$ from the heating plant. The storage of logs for the entire summer season reduces the Moisture Content (MC) from the initial $45 \%-50 \%$ to $25 \%-30 \%$ (Figure 2). Chipping is performed by a sub-contractor in early September; the wood chips produced are directly stored in a warehouse in the logistic platform (Figure 2). The district heating plant has a power of $220 \mathrm{~kW}$ and is able to supply heat to MCL offices, a kindergarten and the headquarters of Public Assistance, with a total production capacity of 6300 cubic meters. The plant is only switched on during winter, and the annual average energy efficiency of the plant is approximately $65 \%$ (Table 1).

Table 1. Main data of the district heating plant of Comunità Montana della Lunigiana.

\begin{tabular}{llll}
\hline Thermal Power Plant & $220 \mathrm{~kW}$ & $\begin{array}{l}\text { Number of public users connected to the } \\
\text { district heating network }\end{array}$ & $3\left(6300 \mathrm{~m}^{3}\right)$ \\
\hline $\begin{array}{l}\text { Wood chip consumption } \\
(\mathrm{CM} 24 \%)\end{array}$ & $72 \mathrm{t} / \mathrm{year}$ & $\begin{array}{l}\text { Number of private users connected to the } \\
\text { district heating network }\end{array}$ & 0 \\
\hline Thermal energy produced & $176 \mathrm{MW} / \mathrm{h} \cdot$ year & Annual Energy efficiency & $65 \%$ \\
\hline
\end{tabular}

In the second chain, the wood chips come from different suppliers: tree protection felling of the coastal pine forest of Pisa; thinning and clean-up of riverbeds of the Garfagnana area; and wood waste provided by a sawmill (Figure 3). The plant is directly managed by the local Municipal Administration which uses the heat produced to warm public facilities: the town hall, the library, the nursery school, the kindergarten, the primary school, plus private households (Figure 3). Private users connected to the network in different time frames: 40 users in the first year, 51 in the third and 80 in the fourth. In this case, the plant consists of two boilers of 500 and $320 \mathrm{~kW}$ power, which work in winter and summer, for the production of domestic hot water. The average annual consumption of wood chips was $624 \mathrm{t}$ f.m. (up to $30 \%$ moisture content) with 51 users, but in the 2012/2013 winter it reached $860 \mathrm{t}$ f.m. (with 80 users) (Table 2). The energy efficiency, on an annual basis, exceeded $77 \%$. 
Table 2. Main data of the district heating plant of San Romano in Garfagnana.

\begin{tabular}{lclc}
\hline Thermal Power Plant & $820 \mathrm{~kW}$ & $\begin{array}{l}\text { Number of public users connected to } \\
\text { the district heating network }\end{array}$ & 5 \\
\hline $\begin{array}{l}\text { Wood chip consumption } \\
\text { (CM 38.7\%) }\end{array}$ & $868 \mathrm{t} \mathrm{f.m./year}$ & $\begin{array}{l}\text { Number of private users connected to } \\
\text { the district heating network }\end{array}$ & 80 \\
\hline Thermal energy produced & $1.934 \mathrm{MW} / \mathrm{h} \cdot$ year & Annual Energy efficiency & $77 \%$ \\
\hline
\end{tabular}

The Municipality (manager) sells the energy to private consumers at $45 € / \mathrm{MWh}$ plus $10 \%$ VAT (Value Added Tax), to which the tax credit must be added. The tax credit is equal to $25.82 € / \mathrm{MWh}$, in accordance with Italian Law 448/98 art. 8c. 10 letter F [17], as amended by Law 354/00 art. 4 par. 4(b) [18]. Overall, the sale of $1 \mathrm{MWh}$ generates $€ 70.82$ of revenue.

\section{Evaluation of the Economic Performance}

The evaluation of the economic performance was carried out following strict accounting-financial guidelines that are helpful in supporting management decisions for Public Administrations: thus, only explicit costs were taken into account [5,14,19-22]. In the present case of ex-post economic evaluations, costs included the actual charges paid by the investor.

The method consisted of:

(1) Defining the cost flows for the biomass district heating plant (fuelled by wood chips) and the fossil district heating plant (fuelled by diesel);

(2) Discounting the two cost flows: Net Present Cost biomass-fired $\left(N P C^{R}\right)$ and Net Present Cost diesel-fired $\left(N P C^{F}\right)[23]$

(3) Comparing two NPCs.

The economic performance indicators are:

* the difference between the two NPCs $(\triangle N P C)$

The equation is:

$$
\Delta N P C=N P C^{R}-N P C^{F}=\sum_{t=0}^{n} \frac{C_{t}^{R}}{(1+r)^{t}}-\sum_{t=0}^{n} \frac{C_{t}^{F}}{(1+r)^{t}}
$$

where: $C_{t}^{R}=$ total annual costs borne at year $n$-th for the biomass-fired plant $(R) ; C_{t}^{F}=$ total annual costs borne at year $n$-th for the diesel-fired plant $(F) ; n=$ duration of the investment; $r=$ interest rate, or discount rate.

* The internal rate of return (IRR) is a rate of return used to measure and compare the profitability of investments (e.g.,: IRR as compared to the mortgage loan interest rate, or to the interest rate of alternative investments);

* The pay-back period (PBP) is the number of years required to recover the funds spent in the investment on biomass heating system;

* The price of Break Even Point (Pbep) for wood chips is the maximum price that the heating plant managers are able to pay to the harvesting enterprises and that covers the total production costs. 
In the case of the district heating plant of Municipality of San Romano in Garfagnana, the district heating plant has two production lines (Figure 4):

(1) The energy for public facilities;

(2) The energy for sale to private users.

In order to check the adequacy of the energy selling price to private users, it has been necessary to estimate energy production costs, by allocating direct and indirect costs to each production line. This necessitated "the full cost method"-an analytical approach used in operational accounting $[8,9,11,12,24-26]$. This approach has enabled the assessment of the unit production costs of thermal energy in mixed plants.

The full cost analysis is based on the classification of costs into:

- $\quad$ Direct costs, i.e., those directly linked to the achievement of the product (example: fuels);

- Indirect costs, i.e., the costs associated with the production inputs used jointly for both products (example: depreciation costs of the materials, administrative costs, maintenance, etc.).

As a result, it was possible to define the cost elements for the two production lines. The most appropriate procedure for allocating the indirect costs was to ascribe them based on the amount of energy product, assuming that the amount of inputs is proportional to the quantity of energy produced by each production line (Figure 4).

The evaluation has also considered the fact that private users were not all yet connected when the plant was ready to start, but they connected at different times. For this reason, the changes in costs that have occurred at different times, according to the level of productivity in different periods, have also been considered: 40 users connected in the first year, 51 in the third year and 80 from the fourth year (2012/2013 winter) (Figure 4).

Figure 4. Energy used by each production line in San Romano in Garfagnana district heating plant.

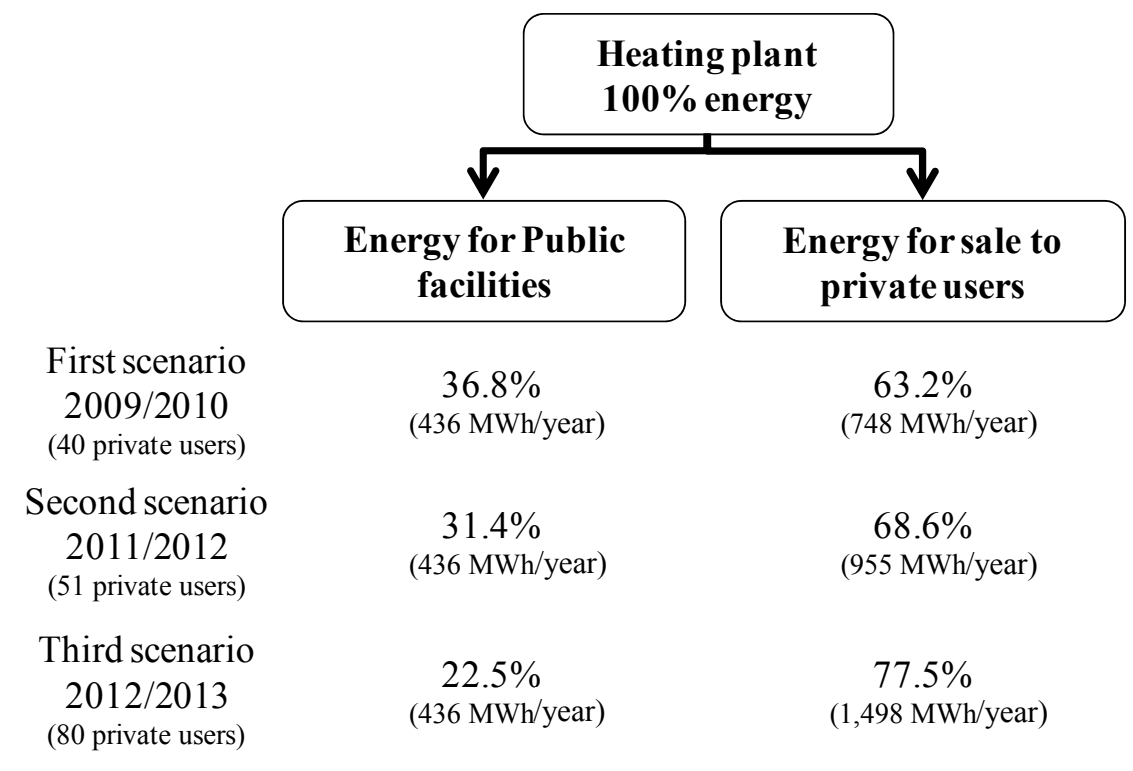




\section{Economic Results}

\section{District Heating Plant of Comunità Montana della Lunigiana}

The investment amounted to $€ 142,999$, fully covered by the CML. It was co-financed by the Tuscany Region on the basis of a voluntary agreement for the sector for $€ 36,000$ (Table 3 ).

Table 3. The main characterizing parameters of district heating plant of Comunità Montana della Lunigiana.

\begin{tabular}{lclc}
\hline Life time & 15 years & Average moisture content & $24 \%$ \\
\hline Applied discount rate & $2.25 \%$ & Gross energy content of wood chips & $3.75 \mathrm{MWh} / \mathrm{t}$ f.m. \\
\hline Production cost of wood chips & $\begin{array}{l}43.50 € / \mathrm{t} \text { (only } \\
\text { explicit costs) }\end{array}$ & Efficiency of the plant & $64.94 \%$ \\
\hline $\begin{array}{l}\text { Average annual consumption } \\
\text { of wood chips }\end{array}$ & $72 \mathrm{t}$ f.m./year & $\begin{array}{l}\text { Average energy content of wood } \\
\text { chips }\end{array}$ & $271 \mathrm{MWh} /$ year \\
\hline
\end{tabular}

- The first result emerging from the monitoring activities is the considerable impact of costs associated to the consumption of electricity (2059 €/year), representing more than $65 \%$ of the costs borne for the supply of wood chips (3147€/year).

- The other important economic aspect is the high efficiency of the investment. In this case, the comparative approach between the two alternative investments $(\triangle N P C)$ estimated a present value of $€ 237,203$ (in terms of savings). It corresponds to an IRR of over $74 \%$ for the assumed 15 -year life of the plant in a payback period of just two years (Table 4).

The wood chips BEP (Break Even Poin) price reaches $303 € / \mathrm{t}$ f.m., confirming the very high efficiency of the investment compared to the production costs in the forestry sector (about $76 € / \mathrm{t}$ f.m. in the territory of Lunigiana-Source CML).

Therefore, it is an extremely efficient investment, since in a 7-year activity it enables the Public Administration to save $€ 106,620$, considering the regional co-financing.

Table 4. Financial efficiency indicators for the investment of Comunità Montana della Lunigiana.

\begin{tabular}{ccc}
\hline \multirow{2}{*}{ Financial efficiency indicators } & \multicolumn{2}{c}{ Considering “only energy for public facilities" } \\
\cline { 2 - 3 } & Without initial funding & With 25\% regional funding \\
\hline Payback time (in years) & 4 & 2 \\
$\triangle N P C(€)$ & 198,933 & 237,203 \\
Internal rate of return $(\%)$ & $32 \%$ & $74 \%$ \\
BEP price of woodchips $(€ / \mathrm{t} \cdot \mathrm{f} . \mathrm{m})$. & 262 & 303 \\
Average savings per year * $(€ /$ year) & 15,773 & 18,808 \\
\hline \multicolumn{2}{c}{$*$ For the same energy output. }
\end{tabular}

The results are in accordance with the ex-ante evaluation. In that case the difference in Net Present Cost was $€ 206,784$ (in terms of savings) and IRR was $54 \%$, but the ex-ante evaluation did not consider electric power consumption. 
District Heating Plant of San Romano in Garfagnana Municipality

The investment made by the Municipality of San Romano in Garfagnana was equal to $€ 684,450$. It was partly co-financed by Tuscany Region within the Extraordinary Investment Program (2005) and POR-Creo call for a total amount of $€ 254,000$ (Table 5).

Table 5. The main characterizing parameters of the district heating plant of Municipality of San Romano in Garfagnana.

\begin{tabular}{|c|c|c|c|}
\hline Life time & 15 years & $\begin{array}{l}\text { Energy produced in the } \\
2011 / 2012 \text { winter season }\end{array}$ & 1,391 MWh/year \\
\hline Applied discount rate & $2.25 \%$ & $\begin{array}{l}\text { Energy produced in the } \\
2012 / 2013 \text { winter season }\end{array}$ & 1,934 MWh/year \\
\hline $\begin{array}{l}\text { Weighted interest rate on } 20 \text {-year } \\
\text { mortgage payments with the } \\
\text { Deposit and Loan Bank }{ }^{(*)}\end{array}$ & $4.803 \%$ & $\begin{array}{l}\text { Efficiency of the plant for } \\
2010 / 2011\end{array}$ & $77.06 \%$ \\
\hline Purchase price of wood chips & 56.5 euro + VAT & $\begin{array}{l}\text { Selling price of thermal } \\
\text { energy }\end{array}$ & $\begin{array}{l}70.28 € / \mathrm{MWh} \\
\text { (including tax credit, } \\
\text { net of VAT) }{ }^{(* *)}\end{array}$ \\
\hline $\begin{array}{l}\text { Annual consumption of wood } \\
\text { chips for } 2009 / 2010 \text { and } \\
2010 / 2011\end{array}$ & 532 t f.m./year & $\begin{array}{l}\text { Energy sold in 2009/2010 and } \\
2010 / 2011\end{array}$ & $748 \mathrm{MWh}$ \\
\hline $\begin{array}{l}\text { Annual consumption of wood } \\
\text { chips for } 2011 / 2012\end{array}$ & 624 t f.m./year & Energy sold in $2011 / 2012$ & $955 \mathrm{MWh}$ \\
\hline $\begin{array}{l}\text { Annual consumption of wood } \\
\text { chips for } 2012 / 2013\end{array}$ & $868 \mathrm{t}$ f.m./year & Energy sold in $2012 / 2013$ & 1,498 MWh \\
\hline $\begin{array}{l}\text { Average moisture content of } \\
\text { wood chips }\end{array}$ & $38.7 \%$ & $\begin{array}{l}\text { Thermal energy consumed by } \\
\text { public facilities }\end{array}$ & $436 \mathrm{MWh} /$ year \\
\hline $\begin{array}{l}\text { Gross energy of wood chips M38 } \\
\text { for } 2009 / 2010 \text { and } 2010 / 2011\end{array}$ & 1,559 MWh/year & $\begin{array}{l}\text { Turnover from energy sales } \\
\text { for } 2009 / 2010 \text { and } 2010 / 2011\end{array}$ & $56,100 € /$ year \\
\hline $\begin{array}{l}\text { Gross energy of wood chips M38 } \\
\text { for } 2011 / 2012\end{array}$ & 1,828 MWh/year & $\begin{array}{l}\text { Turnover from energy sales } \\
\text { for } 2011 / 2012\end{array}$ & $71,625 € /$ year \\
\hline $\begin{array}{l}\text { Gross energy of wood chips M38 } \\
\text { for } 2012 / 2013\end{array}$ & 2,544 MWh/year & $\begin{array}{l}\text { Turnover from energy sales } \\
\text { for } 2012 / 2013 \text { winter }\end{array}$ & $112,350 € /$ year \\
\hline
\end{tabular}

$\left(^{*}\right)$ Interest repayments on 20-year mortgage recalculated on the 15 -year life time; $(* *)$ Tax credit $€ 25.82 € / \mathrm{MWh}$ (in accordance with L. No. 448/98 art. 8 c. 10 [17], letter F, as amended by L. 354/00 art. 4 c. 4bis [18]).

Table 6 shows the economic results under the real-user dynamics of:

- 40 private users connected to the plant in the first and the second year;

- 51 users connected in the third year;

- 80 users connected from the fourth year (2012/2013 winter).

Within this configuration, the "payback period" of the investment is 8 years, the discounted savings will be equal to $€ 331,166$ and the IRR will reach $14.9 \%$, which is higher than the cost of money (4.308\%) obtained from the Cassa Depositi e Prestiti (CDP), an Italian bank for public investors. The BEP price of wood chips will reach €97.9 (Table 6). 
Table 6. Financial efficiency indicators for the investment of Municipality of San Romano in Garfagnana. Overall assessment of the "self-consumption" production line plus the "heating energy sale" production line, assuming the connection of 40 users for the first to the 2 nd years, 51 users for the third year and 80 users in the following years.

\begin{tabular}{|c|c|c|}
\hline \multirow[t]{2}{*}{ Financial efficiency indicators } & \multicolumn{2}{|c|}{$\begin{array}{c}\text { Considering "energy for public facilities and energy for } \\
\text { sale to private users" }(*)\end{array}$} \\
\hline & Without initial funding & With $37 \%$ regional funding \\
\hline Payback time (in years) & $>16$ & 8 \\
\hline$\triangle N P C(€)$ & $-40,055$ & 331,166 \\
\hline Internal Rate of Return (\%) & $\mathrm{NC}$ & $14.9 \%$ \\
\hline BEP price for woodchips ( $€ / \mathrm{t}$ f.m.) & 57.8 & 97.9 \\
\hline Average savings per year* (€/year) & -3176 & 26,258 \\
\hline BEP price of Energy ( $€ / M W h)$ & 77.50 & 54.30 \\
\hline $\begin{array}{l}\text { Average production cost of energy } \\
\text { ex-ante }(€ / M W h)\end{array}$ & \multicolumn{2}{|c|}{147.12} \\
\hline $\begin{array}{l}\text { Average production cost of energy } \\
\text { ex-post (€/MWh) }\end{array}$ & 65.84 & 53.04 \\
\hline
\end{tabular}

(*) These evaluations do not consider the same quantity of energy delivered ex-ante and ex-post. In the ex-post situation, the consumption by users is $37 \%$ higher (Table 4 ). In this case, the appropriate reference parameter is the average production cost of energy.

Under these conditions, the sum of the average annual savings achieved by the public sector and the annual net profit derived from the sale of energy to the 80 private users is $26,258 €$ /year (Table 6). The BEP price of the heat sold is $54.3 € / \mathrm{MWh}$ (including tax credit).

The results are not exactly in line with the ex-ante evaluation. In such case the difference in Net Present Cost was 490,543 € (in savings), PBP (pay-back period) was 6 years and IRR 23.03\%. However, the ex-ante evaluation considered equal energy production ex-ante and ex-post. Moreover, in the ex-ante evaluation the estimate of electric energy costs was much lower, and it was assumed that all 80 private users connected to the network since the first year.

In this case, the traditional economic performance indicators are not appropriate because the evaluation was carried out with respect to the real incurred energy consumption. In the ex-post configuration a $37 \%$ higher production is obtained as compared to the ex-ante conditions (Table 4).

The above data show that the traditional indicators ( $\triangle N P C$, IRR, etc.) underestimate the investment efficiency (Table 6). Table 6 shows the calculated average cost of energy production prior and after the provision of the production facility.

Table 6 clearly indicates that the cost of energy production is much lower in the ex-post than in the ex-ante situation, even in the absence of public funding. More specifically, the cost of energy production reaches $65.84 € / \mathrm{MWh}$, with a cost reduction exceeding $55 \%$. The investment is clearly highly effective even in the absence of funding.

The evaluation of the investment efficiency for private houses has been performed for the single user. The results show a variability that is the result of the mix of technologies installed in each dwelling (e.g., fireplace, wood stove, LPG (Liquefied petroleum gas) boiler, etc.). 
The key variable is the quantity of energy absorbed annually by the network and by each user. In particular, it has been found that the users with the best economic performance are those that use large amounts of heat from the district heating network [21]. In these cases, the average costs of the thermal energy used in the household varies between 50 and $70 € / \mathrm{MWh}$ in relation to the mix of energy consumption. However, in case of substantial use of traditional fuels (firewood), the average costs are between $70 € / \mathrm{MWh}$ and $100 € / \mathrm{MWh}$.

The costs are much lower than in the previous configuration, where the consumption of fossil fuels led to an average cost between $95 € / \mathrm{MWh}$ and $140 € / \mathrm{MWh}$.

However, in the case of San Romano in Garfagnana, it would have been appropriate to connect all the users in a shorter time frame and to sell the thermal energy at a higher price (e.g., $70 € / \mathrm{MWh}$ excluding tax credit, rather than at the currently practiced one, namely $45 € / \mathrm{MWh}$ excluding tax credit). The high margins of competitiveness compared with the energy mix previously consumed by individual users (from 95 to $140 € / \mathrm{MWh}$ ) would have been still maintained.

\section{Sensitivity Analysis of San Romano District Heating Plant Investment}

Sensitivity analysis is useful when attempting to determine the impact that the actual outcome of a particular variable will have if it deviates from expectations. By creating a given set of scenarios, the analyst can determine how changes in one variable will impact the target variable [27].

In this case, the evaluation was not a predictive one but an ex-post investment analysis. Input costs are objectively borne in the phases of implementation and operation of the plant. There are no random variables that might change the economic-financial dynamics of the investment; there is neither risk variability, nor uncertainty about future cash flows. The physical connection of the district heating plant network with customers does not involve any variability in the number of customers or in the quantities of sold energy, as well as in the returns of production factors (fuels, labor, etc.).

The sensitivity analysis (e.g., Montecarlo) is used for the evaluation of complex investments, mostly characterized by high invested capital and high uncertainty about future cash flows (and subsequent high risk) [28-30]. We have not the need to define probability functions with respect to variables, such as sold energy, production costs, etc.

However, in the framework of decision support systems, it is very useful to have a picture of the investment sensitivity with respect to variables that cannot always be controlled by the manager of the district heating plant, namely the selling price of wood chips and the policies of energy selling price.

The first parameter is largely influenced by the territorial context (availability of biomass, number of harvest enterprises, presence of wood industries, etc.); the second parameter is instead guided by local political strategies aimed at maximizing the local consensus and at making biomass energy highly cost effective as compared to fossil-based energy (LPG, gas/diesel oil, kerosene, etc.), because all private users decide whether or not to get connected to the district heating plant, based on the opportunity cost of the competitive fuel.

Table 7 shows the sensitivity analysis of $\triangle N P C$, Payback time, Internal Rate of Return and average savings per year with respect to the wood chip price and the selling energy price for private users. 
Table 7. Sensitivity analysis for financial efficiency indicators as related to some scenarios of energy selling price and wood chip price-Municipality of San Romano in Garfagnana. Red cell scenario is similar to the real-world scenario. Scenario with 40, 51 and 80 users.

\begin{tabular}{|c|c|c|c|c|c|c|c|c|c|}
\hline \multirow{3}{*}{$\triangle N P C(€)$} & & \multicolumn{4}{|c|}{ With $37 \%$ regional funding } & \multicolumn{4}{|c|}{ Without initial funding } \\
\hline & & \multicolumn{4}{|c|}{ Wood chip price $€ / t$ f.m. } & \multicolumn{4}{|c|}{ Wood chip price $€ / t$ f.m. } \\
\hline & & 40 & 60 & 80 & 100 & 40 & 60 & 80 & 100 \\
\hline Selling price of & 70 & 456,482 & 271,117 & 85,752 & $-99,613$ & 85,260 & $-100,105$ & $-285,469$ & $-470,834$ \\
\hline energy $€ /$ Mwh & 90 & 776,386 & 591,021 & 405,656 & 220,291 & 405,164 & 219,799 & 34,434 & $-150,930$ \\
\hline (including tax & 110 & $1,096,289$ & 910,924 & 725,560 & 540,195 & 725,068 & 539,703 & 354,338 & 168,973 \\
\hline credit) & 130 & $1,416,193$ & $1,230,828$ & $1,045,463$ & 860,099 & $1,044,972$ & 859,607 & 674,242 & 488,877 \\
\hline \multicolumn{10}{|c|}{ Payback time (years) } \\
\hline Selling price of & 70 & 6 & 8 & 12 & $>16$ & 13 & $>16$ & $>16$ & $>16$ \\
\hline energy $€ / M w h$ & 90 & 5 & 6 & 7 & 9 & 9 & 11 & 15 & $>16$ \\
\hline (including tax & 110 & 5 & 5 & 5 & 6 & 7 & 8 & 10 & 12 \\
\hline credit) & 130 & 4 & 4 & 5 & 5 & 6 & 7 & 8 & 9 \\
\hline \multicolumn{10}{|c|}{ Internal rate of return $(\%)$} \\
\hline Selling price of & 70 & $18.22 \%$ & $13.16 \%$ & $6.54 \%$ & $\mathrm{NC}$ & $4.33 \%$ & - & $\mathrm{NC}$ & $\mathrm{NC}$ \\
\hline energy $€ / M w h$ & 90 & $25.19 \%$ & $21.35 \%$ & $16.93 \%$ & $11.56 \%$ & $10.31 \%$ & $7.11 \%$ & $3.13 \%$ & $\mathrm{NC}$ \\
\hline (including tax & 110 & $30.94 \%$ & $27.72 \%$ & $24.18 \%$ & $20.21 \%$ & $14.88 \%$ & $12.35 \%$ & $9.49 \%$ & $6.11 \%$ \\
\hline credit) & 130 & $35.92 \%$ & $33.11 \%$ & $30.08 \%$ & $26.79 \%$ & $18.70 \%$ & $16.55 \%$ & $14.21 \%$ & $11.60 \%$ \\
\hline \multicolumn{10}{|c|}{ Average savings per year ( $€ /$ year) } \\
\hline Selling price of & 70 & 36,194 & 21,496 & 6,799 & $-7,898$ & 6,760 & $-7,937$ & $-22,634$ & $-37,332$ \\
\hline energy $€ / M w h$ & 90 & 61,558 & 46,861 & 32,164 & 17,467 & 32,125 & 17,428 & 2730 & $-11,967$ \\
\hline (including tax & 110 & 86,923 & 72,226 & 57,529 & 42,831 & 57,490 & 42,792 & 28,095 & 13,398 \\
\hline credit) & 130 & 112,288 & 97,591 & 82,893 & 68,196 & 82,854 & 68,157 & 53,460 & 38,762 \\
\hline
\end{tabular}

Hence there are 16 scenarios in the absence of funding and 16 scenarios in the presence of funding.

The red cells highlight the scenario that is closest to the real-world. This is a scenario with quite low performances, although it is not evaluated for the same energy ex-ante ex-post. A moderate increase in the price of wood chips could lead to shift the assessment towards grey-colored scenarios, with low or even negative financial efficiency rates.

In order to ensure a greater stability of the investment it would be enough to slightly increase the selling price of energy from the current $70.28 € /$ Mwh to $90 € /$ Mwh (about $65 €$ for families, net of the tax credit). This price is, however, very cheap for private users but it would better secure the investment from the risk of any rise in price of wood chips. However, with these prices the investment would be sustainable even in the absence of Regional funding.

Table 8 instead illustrates the evaluation of the investment sensitivity as related to a change in the timing of private users' connections. The actual scenario involving the connection of 40,51 and 80 users over 4 years is compared with the optimal scenario implying the connection of 80 users since the first year. The results in Table 8 show that the parameter of connection timing has a positive effect on efficiency indicators that, however, is not as high as the above price changes. This aspect needs to be supported together with an appropriate definition of energy selling prices. 
Table 8. Comparison of financial efficiency indicators for two scenarios relating to different timing of connections to the district heating plant of Municipality of San Romano in Garfagnana. Real-world scenario (connection of 40, 51 and 80 users in 4 years), optimal scenario with the connection of 80 users since the first year.

\begin{tabular}{|c|c|c|c|c|c|c|c|c|c|c|}
\hline \multirow[b]{2}{*}{$\begin{array}{l}\text { Scenario of users' } \\
\text { connection }\end{array}$} & \multicolumn{5}{|c|}{ With $37 \%$ regional funding (\%) } & \multicolumn{5}{|c|}{ Without initial funding } \\
\hline & $\begin{array}{c}\text { Payback } \\
\text { time } \\
\text { (years) }\end{array}$ & $\begin{array}{c}\triangle N P C \\
(€)\end{array}$ & $\begin{array}{c}\text { Internal } \\
\text { rate of } \\
\text { return } \\
(\%) \\
\end{array}$ & $\begin{array}{c}\text { Average } \\
\text { savings } \\
\text { per year } \\
(€ / y r)\end{array}$ & $\begin{array}{l}\text { BEP price } \\
\text { of energy } \\
\text { (€/MWh) }\end{array}$ & $\begin{array}{c}\text { Paybac } \\
k \text { time } \\
\text { (years) }\end{array}$ & $\begin{array}{c}\triangle N P C \\
(€)\end{array}$ & $\begin{array}{c}\text { Internal } \\
\text { rate of } \\
\text { return } \\
(\%) \\
\end{array}$ & $\begin{array}{l}\text { Average } \\
\text { savings } \\
\text { per year } \\
\text { (€/year) }\end{array}$ & $\begin{array}{c}\text { BEP } \\
\text { price of } \\
\text { energy } \\
(€ / \mathrm{MWh})\end{array}$ \\
\hline $\begin{array}{l}\text { Real scenario } 40 \text { to } \\
50 \text { to } 80\end{array}$ & 8 & 331,166 & $14.90 \%$ & 26,258 & 54.30 & $>16$ & $-40,055$ & - & $-3,176$ & 77.50 \\
\hline $\begin{array}{l}\text { Optimal scenario } \\
\text { immediately } 80\end{array}$ & 7 & 338,927 & $16.40 \%$ & 27,449 & 51.30 & $>16$ & $-32,295$ & - & $-2,584$ & 73.90 \\
\hline
\end{tabular}

\section{Economic Feasibility of the Forest Energy Chain}

For Tuscan forest harvesting enterprises, the development of this new "production line" requires investments in product processing (new machinery for the processing of wood chips), logistics and the organization of specific sites for different product lines (full tree system, skidding in two times, etc.). As a consequence, the start-up of the "wood chip" production line is strictly related to appropriate guarantees on the economic feasibility of the investment and to the stability of wood chip market price.

A useful indicator to verify the investment's risk relative to the market conditions (market price level of wood chips for thermal plants and cogeneration power plants) is constituted by two safety margins with respect to the price of wood chips (Figure 5). These safety margins link investments and production costs with the local prices of wood chips.

They correlate the production costs of the harvesting enterprise $(c)$ with the market price of wood chips, and the Price of Break Even Point for energy production plants (Pbep) with the market price of wood chips.

Figure 5 shows the two indicators: $S m_{1}$ is an indicator of the investment's risk for the harvesting enterprise relative to the market conditions. It indicates, in percent values, the maximum decrease in the market price of wood chips that can ensure that wood chip production costs are covered. For instance, when the customer of a new thermal plant contacts a forest enterprise asking for the supply of wood chips at a given price, the forest entrepreneur may assess the feasibility of the investment in new wood chipper relative to safety margins $S m_{1}$.

Figure 5. Safety margins in relation to the market price of wood chips for the harvesting enterprises and for biomass energy plants.

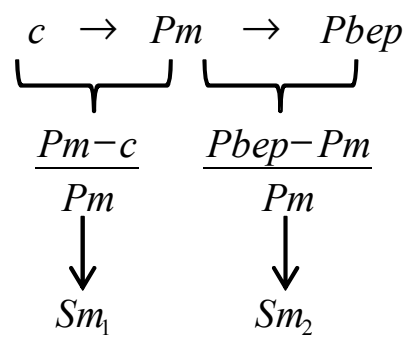


$\mathrm{Sm}_{2}$ is instead an indicator of the investment's risk for the owner/manager of the energy plant relative to the market conditions. It indicates, in percent values, the maximum increase in the market price of wood chips which can guarantee production costs lower or equal to the revenue obtained from the sale of the thermal or thermo-electric energy. For example, when the customer has to assess whether to implement or not a new thermal plant, he/she can test the investment's feasibility through a market survey on chip local prices $(P m)$ and by comparing these results with the price of break-even point (Pbep) of wood chip at the plant. The greater the difference, the higher the investment's safety against possible changes of the market price.

It is evident that the greater the safety margins of the two enterprises in the chain, the greater the guarantees against any (downward or upward) possible variation of wood chip market prices.

By proposing a simulation for the chain of the district heating plant of CML considering that

- The production cost of wood chips is about $76 € / \mathrm{t}$ f.m. (source: Forestry Area CML);

- The price of break-even point of wood chips for the above system is equal to $303 € / \mathrm{t}$ f.m.;

- The current market price for wood chips is in the range of 60-70 €/t f.m.

It is clear that the safety margin $S m_{1}$ is equal to approximately $-6 \%$, while $S m_{2}$ is approximately $321 \%$. In Italy, the current sources of woody biomass are represented almost exclusively by:

- $\quad$ Pruning and thinning;

- Cuts for the starting of high forest;

- $\quad$ Plant protection pruning;

- Cleanups of riverbeds.

These interventions have traditionally a negative stumpage value, but they might be economically viable, if supported by grants (for example the measure 122 of the Rural Development Plan 2007-2013). Thanks to the contribution of the Rural Development Plan, woody biomass is therefore available and forest-cutting cost is very low, even close to zero. Thus, the margin $S m_{1}$ is not currently negative, as it is part of the production costs covered by the above funding.

The managers of district heating systems currently have wide safety margins for the investment, whereas the harvesting company does not have any benefit in harvest activities in the case of joint production (firewood/timber sawmill and wood waste), in the absence of public funding. An increase of market prices for wood chips close to $80-90 €$ could therefore encourage the interest of harvesting enterprises to make cuts for joint productions, while still guaranteeing wide margins for the manager of the district heating system $\left(237 \% \leq S m_{2} \leq 270 \%\right)$.

In the case of the chain of the Municipality of San Romano in Garfagnana, the margin $\mathrm{Sm}_{1}$ for the harvesting company is variable, since the production costs of suppliers may vary from 35 to $40 € / \mathrm{t}$ f.m. for the material resulting from the maintenance of riparian buffer strips, thinning and phytosanitary cutting (considering pruning, tree felling, setting and skidding covered by the Rural Development Plan funding), to $90 € / \mathrm{t} \mathrm{f.m.} \mathrm{for} \mathrm{full} \mathrm{tree} \mathrm{system} \mathrm{production} \mathrm{in} \mathrm{small} \mathrm{size} \mathrm{plots} \mathrm{[31].} \mathrm{Compared} \mathrm{to} \mathrm{the} \mathrm{local}$ market prices of wood chips ( $56.5 €+$ VAT), $S m_{1}$ can vary from $29 \%$ to $47 \%$ for the material resulting from forest maintenance to $-65 \%$ for the material resulting from full tree system forest production. Considering that the Pbep of chips is equal to $97.9 € / \mathrm{t}$.m., the manager of the district heating system has a positive $\mathrm{Sm}_{2}$ margin, which is approximately equal to $70 \%$ of the market price. 
In both cases, the level of risk (risk-return ratio) of the investment, related to the variation of market conditions (price changes), is quite low. Indicators point out a greater level of risk for forest operators but high margins for the managers of energy plants. Therefore, an increase in price of solid biomasses would not have significant effects on the risks of plant managers, but would enable integrating into supply new biomasses resulting not only from forest maintenance cuts (riparian buffer strips, thinning and phytosanitary cutting), but also from clear cutting for woodchip production. However, the same result could be achieved through the structural investments on forest operators, i.e., by funding new more productive and efficient hauling systems for the orographic conditions of Tuscan territories (e.g., cableways).

\section{Evaluation of the Local Socio-Economic Effects}

The district heating systems fuelled by solid biomass are traditionally built in mountain areas, because of the proximity of forest resources and the economic contributions for investments made in these disadvantaged areas (tax credits, grants, etc.). The locations of district heating plants are characterized by the conspicuous use of fossil fuels, such as diesel and LPG, but also of firewood. It is interesting to note that Tuscany is the largest firewood consumer at the national level, reaching approximately 1.4 million cubic meters per year [32-34].

To assess the effects caused by the introduction of a wood chip-fired district heating system on the local community, it is essential to examine the dynamics of energy consumption before and after the establishment of the district heating plants [35].

In the case of the plant of Comunità Montana della Lunigiana, there was a total replacement of fossil fuel (diesel) with renewable fuel (wood chips) (Table 9).

Table 9. Dynamics of fuel consumption for the heating of buildings connected to the district plant of Comunità Montana della Lunigiana.

\begin{tabular}{|c|c|c|c|c|c|c|c|}
\hline \multicolumn{3}{|c|}{ Energy consumption for heating } & \multicolumn{2}{|c|}{ Ex-ante } & \multicolumn{2}{|c|}{ Ex-post } & \multirow{2}{*}{$\begin{array}{c}\% \text { Variation } \\
\text { ex-ante/ex-post }\end{array}$} \\
\hline Sector & Fue & & $\begin{array}{c}\text { Energy } \\
\text { MWh/year }\end{array}$ & $\%$ & $\begin{array}{c}\text { Energy } \\
\text { MWh/year }\end{array}$ & $\%$ & \\
\hline \multirow{6}{*}{ Public } & \multirow{2}{*}{ Fossil energies } & Diesel & 100.00 & $100 \%$ & - & - & $-100 \%$ \\
\hline & & LPG & - & - & - & - & - \\
\hline & \multirow{3}{*}{$\begin{array}{c}\text { Renewable } \\
\text { energies }\end{array}$} & Wood chips & - & - & 176.00 & $100 \%$ & $+100 \%$ \\
\hline & & Firewood & - & - & - & - & - \\
\hline & & Pellets & - & - & - & - & - \\
\hline & \multicolumn{2}{|c|}{ Total } & 100.00 & $100 \%$ & 176.00 & $100 \%$ & $+76 \%$ \\
\hline
\end{tabular}

Based on the analysis of the past and present consumption, as metered at the public facility, some variations in energy use were recorded. In particular, the users of the three facilities (CML headquarters, schools and public assistance operational centers) have perceived a warmer and more comfortable environment, as the current energy used for heating is about $76 \%$ higher than in the previous scenario (with the use of fossil fuels) (Table 9). 
The positive effects on the local forest-wood sector are limited to the involvement of a harvesting enterprise in transport and chipping activities, because the current forestry activities (pruning, felling and skidding) are the same that were carried out previously [36].

A survey was conducted among all private households connected to the district heating plant of San Romano in Garfagnana to identify the types of available heating system and their corresponding energy consumption. As shown in Table 10, the private users connected to the district heating plant are still using other home heating systems. Only through a direct survey it would have been possible to define the previous and current energy mix of individual users.

Table 10. Dynamics of fuel consumption for the heating of buildings connected to the district plant of Municipality of San Romano in Garfagnana.

\begin{tabular}{|c|c|c|c|c|c|c|c|}
\hline \multicolumn{3}{|c|}{ Energy consumption for heating } & \multicolumn{2}{|c|}{ Ex-ante } & \multicolumn{2}{|c|}{ Ex-post } & \multirow[b]{2}{*}{$\begin{array}{c}\text { Variation \% } \\
\text { ex-ante/ex-post }\end{array}$} \\
\hline Sector & Fuel & & $\begin{array}{c}\text { Energy } \\
\text { MWh/year }\end{array}$ & $\%$ & $\begin{array}{c}\text { Energy } \\
\text { MWh/year }\end{array}$ & $\%$ & \\
\hline \multirow{4}{*}{ Public } & \multirow{2}{*}{ Fossil energies } & Diesel & 51.04 & $26 \%$ & 0 & $0 \%$ & $-100 \%$ \\
\hline & & LPG & 149.02 & $74 \%$ & 0 & $0 \%$ & $-100 \%$ \\
\hline & $\begin{array}{l}\text { Renewable } \\
\text { energies }\end{array}$ & Wood chips & - & - & 436.10 & $100 \%$ & - \\
\hline & \multicolumn{2}{|c|}{ Total } & 200.06 & $100 \%$ & 436.10 & $100 \%$ & $118 \%$ \\
\hline \multirow{6}{*}{ Private } & \multirow{2}{*}{ Fossil energies } & Diesel & 296.43 & $20 \%$ & - & $0 \%$ & $-100 \%$ \\
\hline & & LPG & 395.62 & $27 \%$ & - & $0 \%$ & $-100 \%$ \\
\hline & \multirow{3}{*}{$\begin{array}{c}\text { Renewable } \\
\text { energies }\end{array}$} & Wood chips & & $\%$ & 1.498 .00 & $82 \%$ & \\
\hline & & Firewood & 713.84 & $49 \%$ & 315.28 & $17 \%$ & $-56 \%$ \\
\hline & & Pellets & 42.70 & $3 \%$ & 15.51 & $1 \%$ & $-64 \%$ \\
\hline & \multicolumn{2}{|c|}{ Total } & 1448.59 & $100 \%$ & 1828.79 & $100 \%$ & $26 \%$ \\
\hline \multicolumn{3}{|c|}{ Total energy consumption } & 1648.65 & - & 2264.89 & - & $37 \%$ \\
\hline \multicolumn{3}{|c|}{ District heating energy consumption } & - & - & 1934.10 & - & - \\
\hline
\end{tabular}

The results shown in Table 10 point out that the energy consumption of public utilities (two schools, one kindergarten, a library and City Hall) has also increased significantly from about $200 \mathrm{MWh} /$ year to more than $430 \mathrm{MWh} /$ year (by about 118\%). Consequently, the thermal comfort of the users of these public facilities has increased considerably.

The same trend is also evident for private users with a $26 \%$ increase of the thermal energy consumption from $1448 \mathrm{MWh} /$ year to $1828.79 \mathrm{MWh} /$ year in the current situation.

As to private users, there is a shift from fossil fuels and a drastic reduction in the consumption of traditional renewable fuels (firewood and pellets). Firewood decreases from $713.84 \mathrm{MWh} /$ year to 315.28 MWh/year, with a 56\% reduction, while pellets decline from $42.70 \mathrm{MWh} /$ year to $15.51 \mathrm{MWh} /$ year. In quantitative terms, the consumption of firewood has decreased from $432.71 \mathrm{t}$ f.m./year to $199.06 \mathrm{t}$ f.m./year, with a 54\% reduction, while the consumption of pellets has decreased from $9.26 \mathrm{t} / \mathrm{year}$ to $3.26 \mathrm{t} / \mathrm{year}$. The quantities of firewood are affected by the different efficiencies of the technologies used by users (fireplace, stove, fireplace heat, etc.).

Given that many users were self-supplying firewood, the amount purchased on the local market decreased from $295.73 \mathrm{t}$ f.m./year to $124.30 \mathrm{t}$ f.m./year, with an annual expenditure which has 
dropped from $27,650 €$ to $11,691 €$. The amount of self-supplied firewood was $140 \mathrm{t}$ f.m./year, now it is $74.76 \mathrm{t} \mathrm{f} . \mathrm{m}$./year.

Firewood sales declined at a local level to approximately $15,958 € /$ year, while the turnover for the assortment of wood chips increased to about 53,946 €/year.

\section{Evaluation of the Environmental Effects}

In mountainous areas, where the use of firewood for domestic heating is a well-established practice, the introduction of highly efficient district heating systems results in a positive environmental effect, due to a more efficient use of biomass technology [37]. This is obviously true for heating systems, which also involve private households, traditionally linked to the use of wood fuel for domestic heating (Table 10).

At San Romano in Garfagnana, firewood was used by technologies that allowed an average efficiency of $60 \%$, while biomass is currently used with an efficiency of over $77 \%$. In this case, the increased efficiency of the technologies used for heating allowed an annual saving of biomass equal to over $240 \mathrm{t}$ f.m./year. The overall efficiency derives from the weighted sum of the efficiencies of the technologies used by end users (fireplace, stove, fireplace heat, etc.).

The analysis of Table 10 also shows an environmental effect in terms of forest management. More specifically, the decline in demand for firewood (-233 t f.m./year) by the 80 private households connected to the district heating plant of San Romano in Garfagnana caused a 2-ha reduction of the forest areas annually subject to felling. On the other hand, there was a recovery of residual biomass (over $860 \mathrm{t}$ f.m./year) from the forest maintenance activities.

From an environmental point of view, reducing greenhouse gases emissions, such as $\mathrm{CO}_{2}, \mathrm{CH}_{4}$, $\mathrm{N}_{2} \mathrm{O}$, etc., thanks to the production of biomass-fired plants, is of paramount importance. Knowing the amount of energy production and, above all, the quantities of different fuels used in the thermo-chemical process, it is possible to calculate the balance of emissions in tons of $\mathrm{CO}_{2}$ equivalent per type of user, by comparing ex-ante and ex-post emissions (i.e., after the construction of district heating plants).

Assessments of emissions refer to the entire production cycle of different fuels used. The greenhouse gas emissions generated during each stage of the production process are then also estimated for:

- Extraction;

- Processing;

- Storage;

- Energy conversion of fuel for production machinery.

The same production of plant biomass requires the use of fossil fuels and of the so-called grey emissions (Tables 11 and 12).

At the plant of Fivizzano, the annual reduction of greenhouse gas emissions reaches 52.3 tons, corresponding to an over $92 \%$ reduction in emissions, while at the plant of San Romano in Garfagnana, the annual reduction exceeds 222 tons of $\mathrm{CO}_{2}$ equivalent, corresponding to about $80 \%$ reduction.

The average emissions for private users, expressed in tons of $\mathrm{CO}_{2}$ equivalent, decrease from $2.75 \mathrm{t} /$ year to $0.55 \mathrm{t} /$ year. 
Table 11. Dynamics of greenhouse gas emissions in $\mathrm{CO}_{2}$ eq. for the CML plant (Fivizzano).

\begin{tabular}{ccccc}
\hline Type of users & $\begin{array}{c}\text { ex-ante } \mathrm{CO}_{2} \text { eq. } \\
\text { (t/year) }\end{array}$ & $\begin{array}{c}\text { ex-post } \mathrm{CO}_{2} \\
\text { eq. (t/year) }\end{array}$ & $\begin{array}{c}\text { Annual reduction } \\
\mathbf{C O}_{2} \text { eq. (t/year) }\end{array}$ & $\begin{array}{c}\text { Ex-ante/ex-post reduction } \\
\mathbf{C O}_{2} \text { eq. (t/15 years) }\end{array}$ \\
\hline Public users & 56.70 & 4.40 & -52.30 & -784.50 \\
\hline
\end{tabular}

Table 12. Dynamics of greenhouse gas emissions in $\mathrm{CO}_{2}$ eq. for the plant of Municipality of San Romano in Garfagnana.

\begin{tabular}{ccccc}
\hline Type of users & $\begin{array}{c}\text { ex-ante } \mathrm{CO}_{2} \\
\text { eq. }(\mathbf{t} / \mathbf{y} \text { ear) }\end{array}$ & $\begin{array}{c}\text { ex-post } \mathrm{CO}_{\mathbf{2}} \\
\text { eq. }(\mathbf{t} / \mathbf{y e a r})\end{array}$ & $\begin{array}{c}\text { Annual reduction } \\
\mathbf{C O}_{\mathbf{2}} \text { eq. }(\mathbf{t} / \mathbf{y} \text { ear) }\end{array}$ & $\begin{array}{c}\text { Ex-ante/ex-post reduction } \\
\mathbf{C O}_{\mathbf{2}} \text { eq. (t/15 years) }\end{array}$ \\
\hline Public users & 57.65 & 10.90 & -46.75 & -701.25 \\
Private users & 219.95 & 44.00 & -175.95 & -2639.25 \\
Overall balance & 277.60 & 54.90 & -222.70 & -3340.50 \\
\hline
\end{tabular}

\section{Conclusions}

The study illustrates the results of a three-year monitoring activity conducted on two common types of biomass district heating plants, operating in Tuscany [38]. They include a plant supplying public facilities, implemented and run by a public body, and a plant supplying public facilities and 80 private dwellings.

The study has developed ex-post investment analyses to check on whether results have been consistent with ex-ante evaluations. This was targeted to identify the factors that may have reduced or jeopardized the estimated economic performances.

The results of the study point out significant differences, notably for the district heating plants that also involve private users. In the case of the Municipality of San Romano in Garfagnana, where the plant is owned and run by the State, where users are both public and private and biomass is sourced from forest enterprises and sawmills, the ex-ante analysis does not match the ex-post investment evaluation. The occurrence of some information gaps in the design phase has actually affected the economic performances of the investment.

In particular, the sensitivity analysis has shown that the most influential factors include the conditions of the wood biomass local market (market price of wood chips), the accurate definition of the thermal energy selling price and the temporal dynamics of private users' connection to the network. The latter parameter is also closely related to another aspect: the poor knowledge of demographic conditions and the real size of secondary residences.

Looking at the results of the sensitivity analysis relative to 31 possible scenarios, besides the reference scenario, it emerges that to ensure greater stability of the investment it would be enough to slightly increase the energy selling price from the current $70.28 € / \mathrm{Mwh}$ to $90 € / \mathrm{Mwh}$ (corresponding to about $65 €$, net of the tax credit). This price would be extremely cheap for private users, but it would better protect the investment from the risk of wood chip price increases. In case of a wood chip price increase beyond 80 euro/t f.m., the investment would become quite risky.

Moreover, in the case of the district heating plant of Municipality of San Romano in Garfagnana, the traditional economic performance indicators are not suitable, because in the ex-post configuration, there is a $37 \%$ extra energy production as compared to the ex-ante conditions. In particular, if you consider the traditional parameters, the discounted savings will be equal to $€ 331,166$ and the IRR will 
be $14.9 \%$, while the "payback period" of the investment is 8 years. However, if you compare the ex-ante and ex-post average production cost of energy, you observe a $64 \%$ reduction from $147.12 € / \mathrm{MWh}$ to $53.04 € / \mathrm{MWh}$, with a very significant saving.

On the other hand, in the case of the plant of Comunità Montana della Lunigiana that is owned and run by the State and the biomass supply is provided by the public body, ex-post evaluations are very close to ex-ante analyses, although they had a different equivalent energy value.

The results show that in the case of CML plant, the comparative approach between the two alternative investments ( $\triangle N P C$ ) shows a current value of $€ 237,203$ (in savings). It corresponds to an IRR of over $74 \%$ for the assumed 15-year life of the plant in a payback period of just two years. The ex-ante evaluation was close to it.

With regard to the local economic effects, the connection of private households to district heating networks in rural areas causes a strong reduction in the heating expenditure for the local community (ranging from $-64 \%$ to $-22 \%$ for the public facilities of San Romano in Garfagnana) and a reduction of the firewood local market in favor of the wood chip market. The market for wood chips, however, experienced a substantial increase. Given that the current sources of wood chips consist solely of material resulting from forestry activities financed by various measures of the Rural Development Plan, the structuring of the forest energy chains will certainly have amplifying effects for the policies aiming at the improvement of the forest component initiated by the RDP. These interventions are those that make a tangible improvement in the forestry component not only in terms of quality of trees, but also for public safety, by improving the stability of slopes, reducing landslide risk and limiting fire risk.

Consequently, the structuring of forest energy chains, which involve private users, causes an increase in the maintenance and improvement of forestry interventions - which have typically a negative stumpage value - realized by large forest companies. It also induces a reduction in the operations for the production of firewood - that have typically a positive stumpage value - carried out by small family companies with limited equipment.

In order to guarantee a stable and balanced development of the sector and of the relevant chains, it is necessary to verify beforehand the existence of possible trade-offs that can arise in the local economy. By doing so, the biomass production and its energy utilization at local level can become a tool for territorial development, preservation of rural areas and improvement of the community quality of life. These activities favor the development of positive economic start-up businesses linked with forest activities.

\section{Acknowledgments}

The authors thank the editor and two anonymous reviewers for their valuable and constructive suggestions that led to considerable improvements of this paper. This paper is based on the results obtained within the BIOMASS Maritime Cooperation project. BIOMASS is a cross-border cooperation program Italy-France which involves Tuscany, Sardinia, Liguria and Corsica, and a lot of forest consortia, harvest enterprises, Municipalities, and public administrations.

Within the BIOMASS project, several configurations of the forest energy chain, based on district heating technologies with high-efficiency boilers were monitored. The monitoring activities have examined the fuel supply companies and their qualitative characteristics, the business management of 
the heating systems and the end users. The authors thank all the administrations and private enterprises that have made possible the project.

\section{Author Contributions}

The study presented in this paper was a collaborative effort between the authors. The authors contributed collectively to the literature review, analyzed experimental data and manuscript preparation. All authors read and approved the final manuscript for the publication and edited.

\section{Glossary}

$\mathrm{kW} \quad$ Kilowatt (to measure the power of heating district plants)

$\mathrm{kWh} \quad$ Kilowatt hour (to measure energy production from heating district plants)

MWh Megawatt hour $(1000 \mathrm{kWh})$

MC Moisture Content (\%) is a gravimetric water content and is expressed by the difference between the mass of the original sample $\mathrm{W}$ and the mass of dried sample $\mathrm{D}$, divided by the mass of the original sample $\mathrm{W}$

$\mathrm{t}$ f.m. $\quad$ tons of fresh matter (up to $30 \% \mathrm{MC}$ )

$\triangle N P C \quad$ difference between fossil fuel-fired Net Present Cost $\left(N P C^{F}\right)$ and biomass-fired plant Net Present Cost $\left(N P C^{R}\right)$ (in euro)

$N \quad$ duration of the investment (in years)

$C_{t}^{R} \quad$ total annual costs borne in the year $n$-th for the biomass-fired plant $(R)$

$C_{t}^{F} \quad$ total annual costs borne in the year $n$-th for the fossil fuel-fired plant $(F)$

$R \quad$ interest rate, or discount rate (\%)

IRR internal rate of return (\%)

PBP pay-back period (in years)

Pbep price of Break Even Point for wood chips (in euro/t f.m.)

Pm market price of wood chips (in euro)

$C \quad$ production costs of the harvesting company

$S m_{1} \quad$ safety margins 1: maximum decrease in the market price of wood chips Pm that can guarantee the coverage of the production costs for the harvesting company (\%)

$\mathrm{Sm}_{2} \quad$ safety margins 2: maximum increase in the market price of wood chips Pm which can guarantee the coverage of the production costs of the energy production firm (thermal or electric or thermo-electric) (as \%)

$\mathrm{CO}_{2}$ eq. $\quad \mathrm{CO}_{2}$ equivalent: it is the unit of measurement that allows weighing together the emissions of different greenhouse gases. It is a measure of the potential greenhouse effect of each gas. For example, the greenhouse effect of 1 ton of $\mathrm{CH}_{4}$ gas is equal to that of 21 tons of $\mathrm{CO}_{2}$, i.e., it is $21 \mathrm{t} \mathrm{CO}_{2}$ eq.

\section{Conflicts of Interest}

The authors declare no conflict of interest. 


\section{References}

1. Directive 2009/28/EC of the European Parliament and of the Council on the Promotion of the Use of Energy from Renewable Sources and Amending and Subsequently Repealing Directives 2001/77/EC and 2003/30/EC. Available online: http://faolex.fao.org/docs/pdf/eur88009.pdf (accessed on 6 September 2014).

2. Directive 2004/8/EC of the European Parliament and of the Council of 11 February 2004 on the Promotion of Cogeneration Based on a Useful Heat Demand in the Internal Energy Market and Amending Directive 92/42/EEC. Available online: http://eur-lex.europa.eu/legal-content/EN/ TXT/PDF/?uri=CELEX:32004L0008\&from=EN (accessed on 6 September 2014).

3. Directive 2001/77/EC of the European Parliament and of the Council of 27 September 2001 on the Promotion of Electricity Produced from Renewable Energy Sources in the Internal Electricity Market. Available online: http://eur-lex.europa.eu/legal-content/EN/TXT/PDF/?uri=CELEX: 32001L0077\&from=EN (accessed on 6 September 2014).

4. Madlener, R. Innovation diffusion, public policy, and local initiative: The case of wood-fuelled district heating systems in Austria. Energy Policy 2007, 35, 1992-2008.

5. Biezma, M.V.; San Cristobal, J.R. Investment criteria for the selection of cogeneration plants-A state of the art review. Appl. Ther. Eng. 2006, 26, 583-588.

6. Moon, J.H.; Lee, J.W.; Lee, U.D. Economic analysis of biomass power generation schemes under renewable energy initiative with Renewable Portfolio Standards (RPS) in Korea. Bioresour. Technol. 2011, 102, 9550-9557.

7. Rentizelas, A.; Karellas, S.; Kakaras, E.; Tatsiopoulos, I. Comparative techno-economic analysis of ORC and gasification for bioenergy applications. Energy Convers. Manag. 2009, 50, 674-668.

8. Bernetti, I.; Fagarazzi, C.; Fratini, R. A methodology to analyze the potential development of biomass-energy sector: An application in Tuscany. For. Policy Econ. 2004, 6, 415-432.

9. Duerr, W.A. Fundamentals of Forest Economics; McGraw-Hill: New York, NY, USA, 1960.

10. Joye, M.P.; Blayney, P.J. Cost Management Accounting Practice in Australian Manufacturing, Companies: Survey Results, Monograph No. 7; University of Sydney: Sydney, Australia, 1990.

11. Liberatore, C. Contabilità Analitica per le Decisioni Economiche; Edizioni Cedam: Padova, Italy, 1995. (In Italian)

12. Pong, C.; Mitchell, F. Full costing versus variable costing: Does the choice still matter? An empirical exploration of UK manufacturing companies 1988-2002. Br. Account. Rev. 2006 38, 131-148.

13. iBioNet. Available online: www.ibionet.eu (accessed on 5 September 2014).

14. Marinelli, A.; Fagarazzi, C.; Tirinnanzi, A. La biomassa ad uso energetico: Valutazione della sostenibilità economica di alcune filiere foresta-legno-energia in Toscana. In Rivista di Economia e Diritto Agroalimentare; Firenze University Press: Firenze, Italy, 2012. (In Italian)

15. Woodland Energy. La Filiera Legno_Energia Come Strumento di Valorizzazione Delle Biomasse Legnose Agroforestali. Available online: http://www.arsia.toscana.it/UserFiles/File/ Woodland/Brochure_di_presentazione_del_progetto.pdf(accessed on 5 September 2014) (In Italian). 
16. Balsari, P.; Manzone, M. Evaluation of different wood chip storage techniques. In Proceedings of the Forest Engineering: Meeting the Needs of the Society and the Environment (FORMEC), Padova, Italy, 11-14 July 2010.

17. Legge 23 Dicembre 1998, n. 448, "Misure di Finanza Pubblica per la Stabilizzazione e lo Sviluppo", Pubblicata Nella Gazzetta Ufficiale n. 302 del 29 Dicembre 1998-Supplemento Ordinario n. 210. Available online: http://www.camera.it/parlam/leggi/984481.htm (accessed on 6 September 2014) (In Italian).

18. Legge 23 Novembre 2000, n. 354 "Conversione in Legge, Con Modificazioni, del Decreto-Legge 30 Settembre 2000, n. 268, Recante Misure Urgenti in Materia di Imposta sui Redditi delle Persone Fisiche e di Accise", Pubblicata Nella Gazzetta Ufficiale n. 280 del 30 Novembre 2000, Available online: http://www.camera.it/parlam/leggi/003541.htm (accessed on 6 September 2014) (In Italian).

19. König, A. Cost efficient utilization of biomass in the German energy system in the context of energy and environmental policies. Energy Policy 2011, 39, 628-636.

20. Romano, S.; Cozzi, M.; di Napoli, F.; Viccaro, M. Building agro-energy supply chains in the basilicata region: Technical and economic evaluation of interchangeability between fossil and renewable energy sources. Energies 2013, 6, 5259-5282.

21. Schneider, B.; Kaltschmitt, M. Heat supply from woody biomass-An economic analysis. Ecol. Eng. 2000, 16, S123-S135.

22. Van Dael, M.; van Passel, S.; Pelkmans, L.; Guisson, R.; Reumermann, P.; Marquez Luzardo, N.; Witters, N.; Broeze, J. A techno-economic evaluation of a biomass energy conversion park. Appl. Energy 2013, 104, 611-622.

23. Shtub, A. The trade-off between the net present cost of a project and the probability to complete it on schedule. J. Oper. Manag. 1986, 6, 461-470.

24. Fagarazzi, C. La contabilità operativa nelle imprese industriali del settore legno. In Economia Delle Risorse Forestali; Bernetti, I., Romano, S., Eds.; Liguori Editore: Naples, Italy, 2007. (In Italian)

25. Lorenz, G.; Brehm, K.P. Cost accounting in refrigerated warehouses: Direct costing versus full cost accounting. Int. J. Refrig. 1989, 12, 125-136.

26. Saxena, R.S. Cost Accounting Problems (With Full Solutions); Motilal Banarsidass Publishers: Delhi, India, 2007.

27. Rentizelas, A.A.; Tolis, A.I.; Tatsiopoulos, I.P. Optimisation and investment analysis of two biomass-to-heat supply chain structures. Biosyst. Eng. 2014, 120, 81-91.

28. Assadi, M.; De, S. Impact of cofiring biomass with coal in power plants-A techno-economic assessment. Biomass Bioenergy 2009, 33, 283-293.

29. Dornburg, V.; Faaij, A.P.C. Efficiency and economy of wood-fired biomass energy systems in relation to scale regarding heat and power generation using combustion and gasification technologies. Biomass Bioenergy 2001, 21, 91-108.

30. Kima, J.; Realffa, M.J.; Leeb, J.H. Optimal design and global sensitivity analysis of biomass supply chain networks for biofuels under uncertainty. Comput. Chem. Eng. 2011, 35, 1738-1751.

31. Spinelli, R.; Nati, C. Indagine Sulle Disponibilità di Biomasse Forestali in Toscana; Report interno; National Research Council of Italy, Trees and Timber Institute (CNR-IVALSA): Firenze, Italy, 2009. (In Italian) 
32. Istat. Le Utilizzazioni Forestali. Available online: http://seriestoriche.istat.it/index.php? id $=7 \&$ user_100ind_pi1\%5Bid_pagina $\% 5 \mathrm{D}=36 \& \mathrm{cHash}=03 \mathrm{f6ebd} 7$ aeaceeccd0e3fa1e $729 \mathrm{f} 8268$ (accessed on 5 September 2014).

33. Pettenella, D.; Andrighetto, N. Le biomasse legnose a fini energetici in Italia: Uno sleeping giant? Agriregioni Eur. 2011, 7, 18-22. (In Italian)

34. Regione Toscana, ARSIA. Rapporto Sullo Stato Delle Foreste in Toscana 2009; ARSIA: Perugia, Italy, 2010. (In Italian)

35. Krajnca, N.; Domacb, J. How to model different socio-economic and environmental aspects of biomass utilization: Case study in selected regions in Slovenia and Croatia. Energy Policy 2007, $35,6010-6020$.

36. Cozzi, M.; di Napoli, F.; Viccaro, M.; Romano, S. Use of forest residues for building forest biomass supply chains: Technical and economic analysis of the production process. Forests $\mathbf{2 0 1 3}$, 4, 1121-1140.

37. Wei, Q.; Qu, Y.; Tan, T. Mass and heat balance calculations and economic evaluation of an innovative biomass pyrolysis project. Front. Chem. Sci. Eng. 2011, 5, 355-361.

38. Fagarazzi, C.; Nibbi, L.; Tirinnanzi, A. Come monitorare le filiere e gli impianti esistenti al fine di massimizzare la resa economica e migliorare l'impatto ambientale. In Politiche e Strumenti per la Valorizzazione delle Biomasse Come Fonte Energetica Rinnovabile-Le Biomasse Nell'area di Cooperazione Transfrontaliera: Disponibilità di Risorsa e Proposte di Governance; Provincia di Lucca; Lucca, Italy, 2011. (In Italian)

(C) 2014 by the authors; licensee MDPI, Basel, Switzerland. This article is an open access article distributed under the terms and conditions of the Creative Commons Attribution license (http://creativecommons.org/licenses/by/3.0/). 